\title{
Intraamniotic Administration of an Adenoviral Vector for Gene Transfer to Fetal Sheep and Mouse Tissues
}

\author{
ANDREAS HOLZINGER, BRUCE C. TRAPNELL, TIMOTHY E. WEAVER, JEFFREY A. WHITSETT, \\ AND HARRIET S. IWAMOTO \\ Divisions of Pulmonary Biology [A.H., T.E.W., J.A.W.] and Neonatology [H.S.I.], Department of \\ Pediatrics, University of Cincinnati College of Medicine, Cincinnati, Ohio 45229, and Genetic Therapy, \\ Inc. [B.C.T.], Gaithersburg, Maryland 20878
}

\section{ABSTRACT}

Replication-deficient adenoviruses have been used to transfer various genes of interest to mammalian tissues in vivo. Effective gene therapy for inborn genetic defects presenting with significant morbidity and mortality at birth will require correction of the defect prenatally. To test the hypothesis that intraamniotically administered adenovirus transfers gene expression to fetal tissues, replication-deficient human type 5 adenovirus carrying the lac $Z$ gene which encodes nuclear-targeted bacterial $\beta$-galactosidase (Av1LacZ4) was instilled into the amniotic cavity of fetal sheep $\left(10^{10}\right.$ to $\left.1.5 \times 10^{11} \mathrm{pfu}\right)$ and fetal mice $\left(10^{9} \mathrm{pfu}\right)$ at 0.8 term gestation. Amniotic membranes and gastrointestinal and respiratory tract tissues were harvested after $3 \mathrm{~d}$, bacterial $\beta$-galactosidase activity was determined by 5-bromo-4-chloro-3indoyl- $\beta$-D-galactopyranoside (X-gal) enzyme-histochemistry, and tissue integrity was assessed in sections stained with hematoxylin and eosin. Bacterial $\beta$-galactosidase activity was abundant in amniotic membranes and present in lower levels in esophagus, stomach, and small intestine as well as in conducting airways and pulmonary alveoli. To determine whether gene transfer by intraamniotic injection of adenovirus was dosedependent, Av1Luc1, an adenoviral vector carrying the gene for luciferase $\left(10^{5}-10^{9} \mathrm{pfu}\right)$, was injected intraamniotically into fetal mice at 0.8 term gestation. Luciferase activity measured after $3 \mathrm{~d}$ in tissue homogenates of Av1Lucl-treated fetal mice revealed a linear dose response in amniotic membranes and gastrointestinal and respiratory tract organs. Intraamniotic administration of an adenoviral gene vector leads to expression of the transferred gene in amniotic membranes as well as in fetal gastrointestinal and respiratory tract tissues in a dose-dependent manner. (Pediatr Res 38: 844-850, 1995)

Abbreviations
pfu, plaque-forming unit
X-gal, 5-bromo-4-chloro-3-indoyl- $\beta$-D-galactopyranoside
A variety of techniques for gene transfer to mammalian tissues in vivo are currently under investigation. Recombinant adenoviral vectors rendered replication-deficient by virtue of deletions of the E1 and E3 transcriptional units have been used to transfer a variety of genes to mammalian epithelial cells in vivo (1-7). DNA transferred into mammalian cells by an adenoviral vector is thought to remain episomal and is not integrated into the host cell genome. This technique holds promise for somatic gene therapy for inheritable diseases such as cystic fibrosis or $\alpha_{1}$-antitrypsin deficiency. Other genetic diseases-such as surfactant protein B deficiency $(8-10)$ present with severe morbidity and mortality immediately after birth, and successful gene therapy will likely require the cor-

Received February 21, 1995; accepted July 18, 1995

Correspondence: Harriet S. Iwamoto, Ph.D., Department of Pediatrics, Neonatology/ TCHRF Division, Children's Hospital Medical Center, 3333 Burnet Ave., Cincinnati, OH 45229-2899.

Supported by the Center for Gene Therapy of Cystic Fibrosis and Other Lung Diseases, National Institutes of Health HL 51832 and the Cystic Fibrosis Foundation. rection of the defect prenatally, before irreversible structural changes develop. Prenatal diagnosis - as a prerequisite for such an approach-has been demonstrated to be feasible for this defect (11).

Fetal tissues in utero are accessible for gene transfer with adenovirus. Previous studies have demonstrated successful gene transfer by adenovirus to fetal sheep lung in utero using chronically implanted intratracheal catheters $(12,13)$. The amniotic cavity is more easily accessible, and intraamniotically administered substances have been demonstrated to distribute freely even to the most distal parts of the respiratory tract (14-16). This is made possible by simple diffusion and fetal breathing activity, although there is a net outflow of lung fluid into the amniotic cavity. Adenoviruses administered into the amniotic fluid can also gain access to the gastrointestinal tract by fetal swallowing.

In this study, transfer of the reporter genes $l a c Z$ and $l u c$ to fetal tissues by intraamniotic injection of an adenoviral vector is investigated. lacZ is an Escherichia coli-derived gene en- 
coding $\beta$-galactosidase (EC 3.2.1.23). This enzyme, which contains a nuclear localization sequence, can be detected histologically by enzyme-histochemical methods (17). Luciferase (EC 1.13.12.7), the corresponding product of the luc gene derived from the common firefly (Photinus pyralis), is used for quantitation in tissue homogenates in the dose response study because it does not occur naturally in mammalian tissues, and highly sensitive luminometric quantitation protocols are available (18).

\section{METHODS}

Replication-deficient human type 5 adenoviruses Av1LacZ4 and Av1Luc1 were provided by Genetic Therapy Inc., Gaithersburg, MD, in titers from 1.0 to $2.3 \times 10^{11} \mathrm{pfu} / \mathrm{mL}$. Portions of the E1 and E3 regions of the adenoviral genome were deleted to render the adenoviruses replication-deficient and to create space for the insertion of the gene to be transferred. The virus contained a transgene expression cassette consisting of the Rous sarcoma virus promoter, the transgene [E. coliderived nuclear-targeted $\beta$-galactosidase (Av1LacZ4) or firefly luciferase (Av1Luc1)] followed by the Simian virus 40 poly(A) signal inserted into the site of the deleted El region $(19,20)$. Viruses were constructed, propagated, purified and titered as previously described $(3,19)$.

\section{Fetal Sheep}

Surgical procedures. Five ewes with singleton or twin pregnancies were obtained from a commercial supplier at least 1 wk before surgery. They had free access to standard laboratory diet and water until $24 \mathrm{~h}$ before surgery, when they had access to water only.

At $109-112 \mathrm{~d}$ of gestation the ewes were sedated by i.v. injection of pentobarbital ( $30 \mathrm{mg} / \mathrm{kg})$, intubated, and ventilated with oxygen. Low spinal anesthesia was achieved by injection of $4 \mathrm{~mL}$ of $1 \%$ tetracaine hydrochloride, and the ewes were secured in a supine position. Pentobarbital (150-200 mg) was injected i.v. every 10-15 min to maintain anesthesia. Using aseptic procedures, polyvinyl catheters (inner diameter: 1.3 $\mathrm{mm}$, outer diameter: $2.3 \mathrm{~mm}$ ) were inserted into the maternal left femoral artery and vein and advanced to the inferior vena cava and descending aorta. Through a midline incision of the abdomen, the pregnant horn of the uterus was exposed, a small hysterotomy performed, and polyvinyl catheters (inner diameter $0.8 \mathrm{~mm}$, outer diameter $1.2 \mathrm{~mm}$ ) were inserted into a fetal artery and vein. A catheter was also placed into the amniotic cavity. The incisions were sutured in layers, and the catheters were secured and passed through the abdominal wall to the ewe's flank where they were protected by a cloth pouch sewn to the skin. Gentamicin (40 mg), ampicillin ( $1 \mathrm{~g}$ ), and metronidazole $(50 \mathrm{mg}$ ) were administered into the amniotic cavity and maternal vein during surgery as well as on postoperative $d$ 1 through 3.

Experimental procedures. Fetal well being was assessed by analyzing fetal arterial blood for $\mathrm{pH}, \mathrm{PCO}_{2}$ and $\mathrm{PO}_{2}(170$ $\mathrm{pH} / \mathrm{Blood}$ Gas Analyzer, Ciba Corning), $\mathrm{Hb}$ concentration, and $\mathrm{O}_{2}$ saturation (OSM2 Hemoximeter, Radiometer Copenhagen).
Five to $7 \mathrm{~d}$ after surgery, $1 \times 10^{10} \mathrm{pfu}(n=2)$ or $1.5 \times 10^{11}$ pfu $(n=4)$ of Av1LacZ4 were instilled into the amniotic cavity. Two fetuses received an injection of an equivalent volume of $0.9 \%$ saline and served as controls. Two to $3 \mathrm{~d}$ after virus or saline administration, amniotic membranes and fetal respiratory and gastrointestinal tract tissues were obtained. The ewes were anesthetized with sodium pentobarbital $(30 \mathrm{mg} / \mathrm{kg})$ and secured in a supine position. The fetal head was exposed, and fixative [4\% paraformaldehyde in phosphate-buffered $0.9 \%$ saline (PBS; $80 \mathrm{mM} \mathrm{Na} \mathrm{HPO}_{4}, 20 \mathrm{mM} \mathrm{NaH}_{2} \mathrm{PO}_{4}, 150$ $\mathrm{mM} \mathrm{NaCl}, \mathrm{pH}$ 7.4)] was instilled into the fetal trachea at a pressure of $30 \mathrm{~cm} \mathrm{H}_{2} \mathrm{O}$. The fixative was also instilled into the esophagus and postpyloric duodenum. At least 15 min later, the larynx, trachea, lungs, esophagus, stomach, and $100 \mathrm{~cm}$ of proximal small intestine were isolated, cut into $1 \mathrm{~cm}^{3}$ pieces, and immerse-fixed for $24 \mathrm{~h}$ at $4^{\circ} \mathrm{C}$. Amniotic membranes were obtained and carefully secured in fixative such that the original geometry was preserved as closely as possible. All tissues except amniotic membranes were immersed in $20 \%$ sucrose for $24 \mathrm{~h}$ at $4^{\circ} \mathrm{C}$, embedded in M1 embedding matrix (Lipshaw, Pittsburgh, PA), and stored at $-80^{\circ} \mathrm{C}$.

Frozen tissue sections $(12 \mu \mathrm{m})$ were obtained from 20 randomly chosen blocks of lung tissue representing all five lobes as well as from all other embedded tissues. One $1.5-\mathrm{cm}$ long piece of tissue was chosen from each 10-cm segment of small intestine distal to the pylorus (11 pieces in total). These tissue sections and five $1.5 \times 2 \mathrm{~cm}$ of amniotic membrane, randomly chosen from different areas, were stained for bacterial and endogenous $\beta$-galactosidase activity. Hematoxylin/ eosin staining was performed to evaluate general tissue morphology.

To determine the presence of bacterial $\beta$-galactosidase activity, tissue sections and amniotic membrane pieces were placed on glass slides coated with Vectabond (Vector Laboratories Inc., Burlingame, $\mathrm{CA}$ ) and incubated in an X-gal solution, pH $7.4\left[5 \mathrm{mM} \mathrm{K}_{3} \mathrm{Fe}(\mathrm{CN})_{6}, 5 \mathrm{mM} \mathrm{K}_{4}(\mathrm{CN})_{6}, 2 \mathrm{mM} \mathrm{MgCl}_{2}\right.$, $1 \mathrm{~g} / \mathrm{L} \mathrm{X}$-gal in $50 \mathrm{~mL} / \mathrm{L} N, N$-dimethylformamide in PBS] for $24 \mathrm{~h}$ at $32^{\circ} \mathrm{C}$. Tissue sections were then rinsed in $3 \%$ DMSO in PBS for $5 \mathrm{~min}$, dehydrated, counterstained with nuclear fast red (amnion) or eosin (all other tissues), coverslipped, and examined microscopically for the presence of blue nuclear staining. In amniotic membrane preparations, the average percentage of positively staining epithelial cells was determined by counts of 10 randomly chosen areas of each of the five membrane samples. Endogenous $\beta$-galactosidase activity was examined by incubating tissues in X-gal solution, $\mathrm{pH} 5.2(5 \mathrm{mM}$ $\mathrm{K}_{3} \mathrm{Fe}(\mathrm{CN})_{6}, 5 \mathrm{mM} \mathrm{K}_{4}(\mathrm{CN})_{6}, 2 \mathrm{mM} \mathrm{MgCl}_{2}, 1 \mathrm{~g} / \mathrm{L} \mathrm{X}$-gal in 50 $\mathrm{mL} / \mathrm{L} N, N$-dimethylformamide, $107.2 \mathrm{mM} \mathrm{Na}_{2} \mathrm{HPO}_{4}$, and 46.4 $\mathrm{mM}$ citric acid). Tissues were processed as described above. Additional tissue sections were stained with hematoxylin and eosin.

\section{Fetal Mice}

Four National Institutes of Health Swiss mice were anesthetized (2\% Fluothane) on d 15 of gestation. Using sterile procedures, we exposed the uterus through a midline abdominal incision. The fetuses were injected intraamniotically with 
HOLZINGER ET AL.
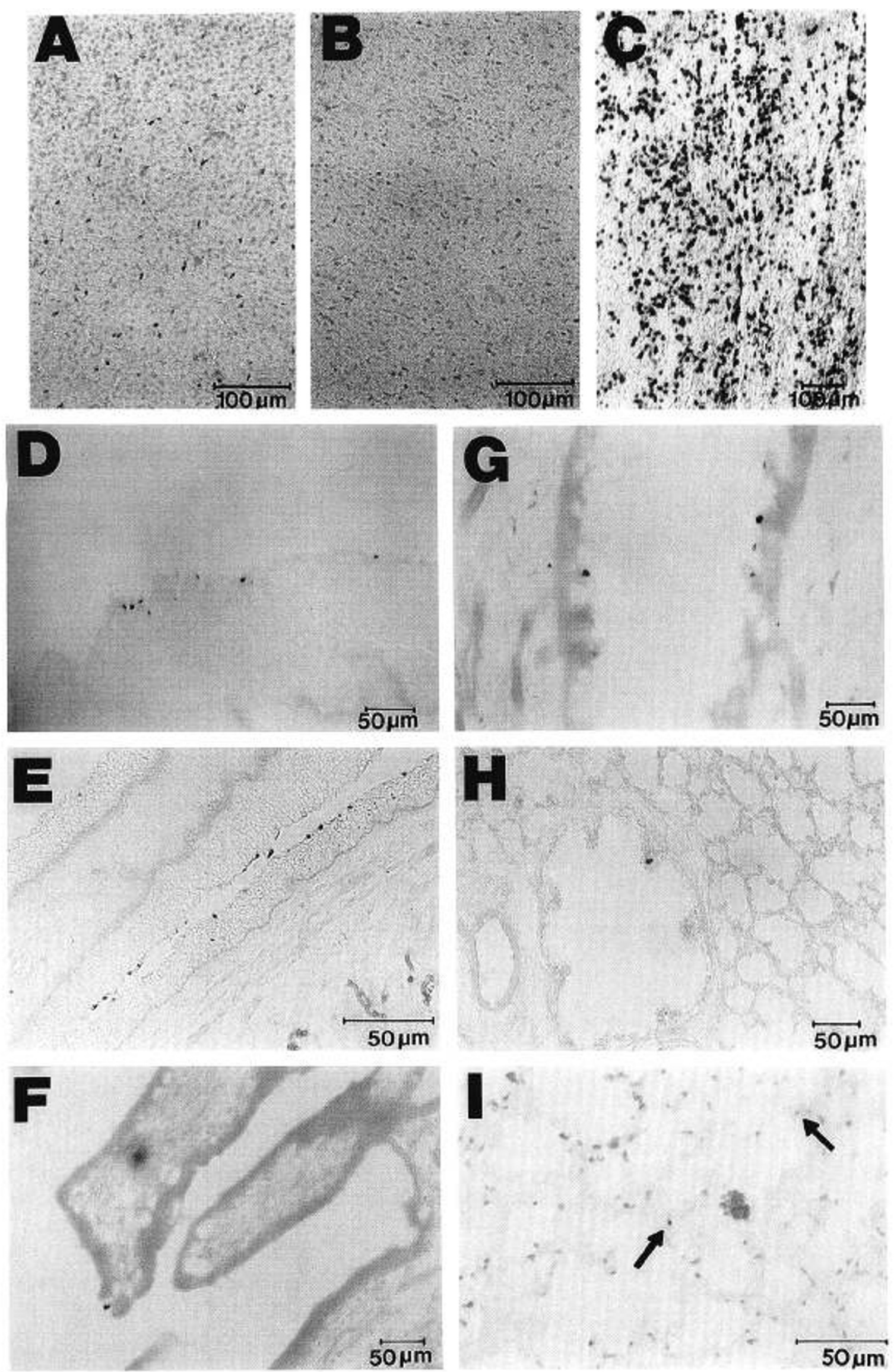

Figure 1. Histology of fetal sheep tissues. (A) Blue cytoplasmic staining indicates the presence of endogenous $\beta$ galactosidase in amniotic membrane of a control animal incubated with X-gal solution, $\mathrm{pH}$ 5.2. (B) Absence of blue nuclear staining in amniotic membrane of a control fetus incubated with X-gal solution $\mathrm{pH}$ 7.4. (C) Blue nuclear staining indicates $E$. coli-derived $\beta$-galactosidase in amniotic membrane of an Av1LacZ4-treated fetal sheep incubated with X-gal 
either $10^{9} \mathrm{pfu}$ of Av1LacZ4 or vehicle (Hanks' balanced salt solution). On d 18 of gestation, the mice were anesthetized $(0.25 \mathrm{mg}$ of acepromazine, $0.5 \mathrm{mg}$ of xylazine, and $10 \mathrm{mg}$ of ketamine- $\mathrm{HCl}$ intraperitoneally). The uterus was incised, and the fetuses were removed with their membranes intact and analyzed histologically in the same way as fetal sheep tissues with the exception that fixation was performed on whole fetuses.

To determine the dose response of an intraamniotically administered adenoviral vector, seven timed pregnant National Institutes of Health Swiss mice of $15 \mathrm{~d}$ of gestation ( 72 fetuses) were randomly assigned to receive either $10^{5}, 10^{6}, 10^{7}, 10^{8}$, or $10^{9}$ pfu of Av1Luc1 or vehicle intraamniotically using the technique described above. Amniotic membranes, fetal respiratory tract organs (trachea, lungs), and gastrointestinal tract organs (esophagus, stomach, $1 \mathrm{~cm}$ of proximal small bowel) were isolated. Organs were pooled for each dose group, immersed in $1 \mathrm{~mL}$ of lysis buffer (Luciferase Assay System; Promega, Madison, WI), and homogenized. The homogenate was centrifuged at $10,000 \mathrm{rpm}$ at $4^{\circ} \mathrm{C}$ for $1 \mathrm{~min}$ and the supernatant was stored at $-80^{\circ} \mathrm{C}$.

Luciferase activity was quantified in triplicate in $20-\mu \mathrm{L}$ aliquots of supernatant using a luminometric assay (Luciferase Assay System; Promega) performed on a Monolight 2010 luminometer (Analytical Luminescence Laboratories, San Diego, CA). Light emission, which is proportional to enzyme activity, was expressed in means of relative light units and normalized for the total protein content of each sample as determined by the Lowry et al. (21) procedure. The interassay coefficient of variation for the luciferase assay was $4 \%$.

All animal procedures in the present studies were approved by the Animal Care and Use Committee of the Children's Hospital Research Foundation, Cincinnati, $\mathrm{OH}$, and followed the guidelines defined in the National Institutes of Health Guide for the Care and Use of Laboratory Animals.

\section{RESULTS}

Fetal sheep. All fetal sheep were in good health throughout the study. Mean arterial blood $\mathrm{pH}$ before virus administration was $7.41 \pm 0.07$ (mean $\pm \mathrm{SD}), \mathrm{Po}_{2}$ and $\mathrm{PCO}_{2}$ were $2.46 \pm 0.43$ and $7.81 \pm 0.20 \mathrm{kPa}$, respectively, the $\mathrm{Hb}$ concentration was $10.86 \pm 0.99 \mathrm{~g} / \mathrm{dL}$, and the blood $\mathrm{O}_{2}$-saturation was $51.8 \pm$ $12.5 \%$. None of these values changed significantly after virus injection.

Endogenous $\beta$-galactosidase activity was found in all tissues examined by staining with $\mathrm{X}$-gal solution, $\mathrm{pH} 5.2$ (amniotic membrane, Fig. $1 A$ ). Endogenous $\beta$-galactosidase activity was localized in the cytoplasm and clearly distinguishable from bacterial $\beta$-galactosidase activity which was predominanly nuclear. Endogenous $\beta$-galactosidase activity was not detectable at $\mathrm{pH} 7.4$ in any tissue (Fig. $1 B$ ).

Adenovirus injection into the amniotic cavity resulted in bacterial $\beta$-galactosidase gene expression in amniotic mem- brane epithelial cells. The intensity and distribution of $\beta$-galactosidase activity was variable. Amniotic membrane epithelium of three (out of six) treated fetuses expressed lacZ (Fig. $1 C$ ). Of the five randomly chosen pieces of amniotic membrane of each of these fetuses, two to four stained positive. The level of expression also varied within each of the positive samples. The average percentage of positively staining amnion epithelial cells ranged from 0.8 to $7.4 \%$, but areas in which $40 \%$ of cells expressed lac $Z$ were identified. In the three fetuses in which no blue nuclear staining was found in amniotic membranes, bacterial $\beta$-galactosidase activity was not detected in any other tissues $(n=2)$ or was detected in the gastrointestinal tract only $(n=1)$.

The gastrointestinal tract stained positive for bacterial $\beta$-galactosidase. Blue nuclear staining was observed in esophagus and stomach of four fetuses and in the duodenum of one of these fetuses (Fig. 1, $D-F$ ). A gradient of $\beta$-galactosidase activity was observed only in the esophagus, where blue nuclear staining was greatest in areas close to the pharynx and least in areas close to the esophageal sphincter. No gradient pattern of nuclear blue staining was obvious in gastric epithelium or small intestine, rather a more patchy distribution of $\beta$-galactosidase activity was observed. The jejunum did not contain bacterial $\beta$-galactosidase in any animal.

The respiratory tract of three fetuses was observed to contain bacterial $\beta$-galactosidase activity. The abundance of blue cells in laryngeal epithelium (Fig. $1 G$ ) was greater than in tracheal epithelium. Cells staining positively for bacterial $\beta$-galactosidase were rare in tracheal epithelium and detected in only two fetuses. The epithelium of a small bronchus and a bronchiolus (Fig. $1 H$ ) - both of the same fetus-expressed the transferred lac $Z$ gene. Lung tissue of three fetuses expressed bacterial $\beta$-galactosidase (Fig. 1I). In two fetuses expression was detected in all lung lobes, and in one fetus expression was found to be confined to the right middle and lower lobe. In these fetuses bacterial $\beta$-galactosidase expression was detected in alveolar epithelium and interstitial tissue of alveolar septa. All airway tissues were rich in endogenous $\beta$-galactosidase activity.

All tissues analyzed had normal structure and no evidence of any inflammatory response as determined by hematoxylin/ eosin staining. No tissues from control fetuses contained nuclear targeted bacterial $\beta$-galactosidase activity (data not shown).

Fetal mice. Adenoviral vectors were demonstrated capable of transferring lac $Z$ and luc expression to fetal mouse tissues. Histologic analysis of fetal mice treated with $10^{9} \mathrm{pfu}$ of Av1LacZ4 revealed expression of bacterial $\beta$-galactosidase in amniotic membranes, in the respiratory tract from the nasal cavity to lung tissue, and in the gastrointestinal tract from the oral cavity to the small intestine (Fig. 2). Overall, the density of lacZ expressing cells appeared to be higher than in the fetal sheep.

solution, pH 7.4. (A-C, nuclear fast red counterstain.) $(D-F)$ Expression of bacterial $\beta$-galactosidase in the gastrointestinal tract; $D$, esophageal epithelium; $E$, gastric mucosa; and $F$, duodenum. $(G-l)$ Expression of bacterial $\beta$-galactosidase in the respiratory tract: $G$, larynx; $H$, bronchiolus; $I$, pulmonary alveoli. (D-I,X-gal staining at $\mathrm{pH} 7.4$, eosin counterstain.) 

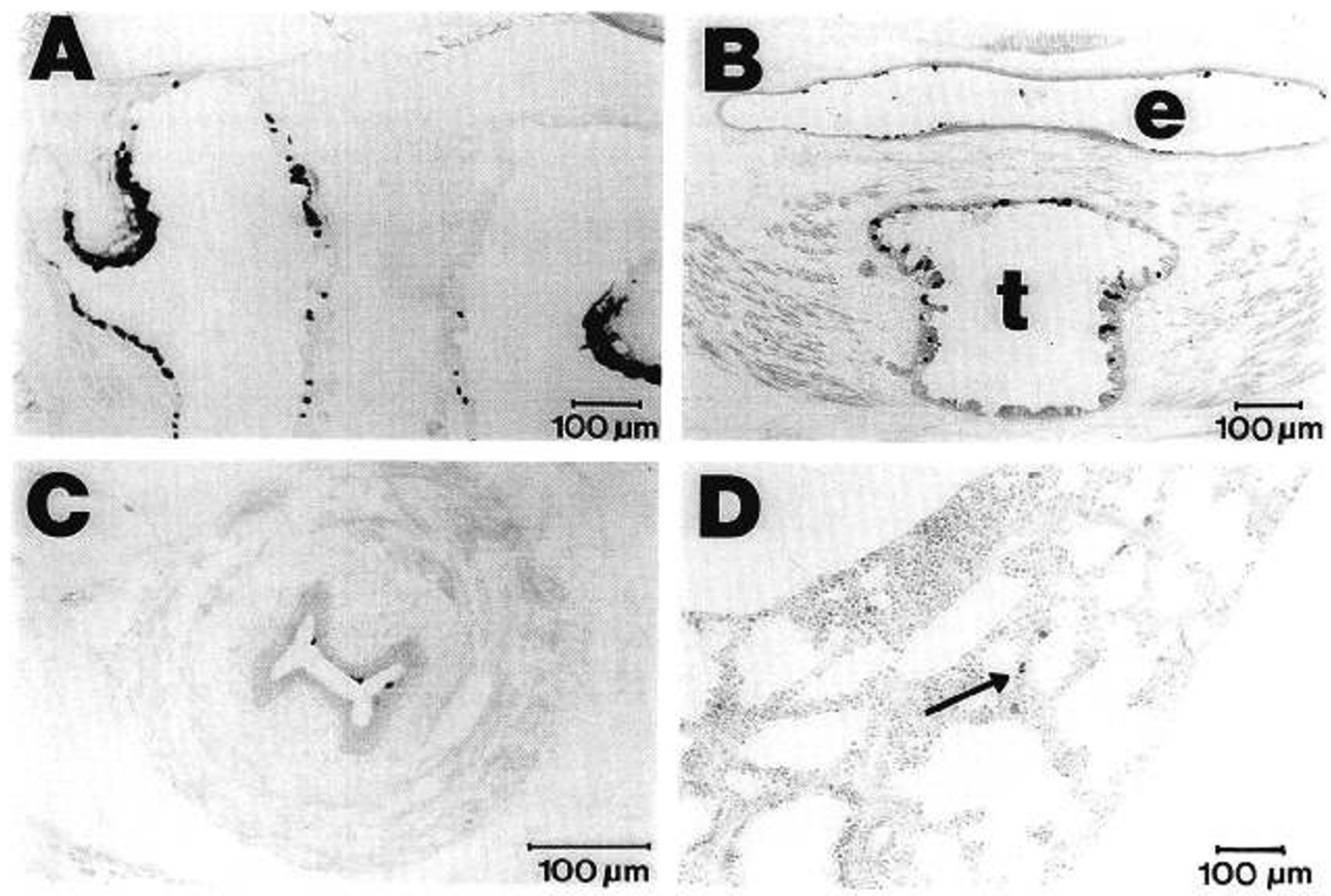

Figure 2. Histology of fetal mouse tissues; $10^{9} \mathrm{pfu}$ of Av1LacZ4 were injected into the amniotic cavity, tissues were stained with X-gal solution, pH 7.4. Blue nuclear staining indicates the presence of $E$. coli-derived $\beta$-galactosidase. $A$, nasal cavity; $B$, proximal esophagus $(e)$ and trachea $(t) ; C$, esophagus at the level of the heart; $D$, lung. (A-D, eosin counterstain.)

In the dose-response study, all seven maternal animals survived the surgical and injection procedures. One of the dams delivered prematurely on $\mathrm{d} 17$ of gestation. These fetuses were not included in the study. All of the remaining 62 mouse fetuses survived treatment and were analyzed. Luciferase activity in tissue homogenates of Av1Luc1-treated fetal mice was dose-dependent in all tissues examined. Consistent with $\beta$-galactosidase abundance, luciferase activity/ $\mu \mathrm{g}$ of total protein was significantly higher in amniotic membranes than in gastrointestinal and respiratory tract tissues. A gradient of luciferase activity, decreasing from proximal to distal, was observed in both the gastrointestinal and respiratory tracts (Fig. $3)$.

\section{DISCUSSION}

This study demonstrates that gene transfer to fetal tissues is feasible. Administration of a replication-deficient adenoviral gene vector to the amniotic cavity of fetal sheep and mice resulted in expression of the transferred bacterial $\beta$-galactosidase and firefly luciferase cDNA in amniotic membranes and gastrointestinal and respiratory tract organs. Abundance of the corresponding products of these genes was greatest in amniotic membranes and significantly less in gastrointestinal and respiratory tract. Expression levels of transferred genes were dosedependent.

Adenoviral vectors are capable of transducing a variety of epithelial and nonepithelial cells. Replication-deficient human type 5 adenovirus, which has been demonstrated to be useful for gene transfer in vivo to the cotton rat $(1,20)$, baboons (4), and macaques (22) is an efficient gene vector also in sheep (12, $13,23)$ and mouse tissues. Whether its efficiency in various animal models is different from that in humans is not known. In accordance with wild type type 5 human adenovirus, the adenoviral vectors used in these studies can infect respiratory and gastrointestinal tissues. Intraamniotically administered substances diffuse quickly throughout this compartment and even to the most distal parts of the respiratory tract (14-16). Diffusion is probably the main mechanism by which distal airways are exposed, despite the constant outflow of lung fluid into the amniotic cavity. Fetal swallowing of amniotic fluid exposes the surface of the gastrointestinal tract to substances in the amniotic cavity. The results from our studies demonstrate that gene therapy can be initiated before birth by virtue of intraamniotic administration of adenoviral vectors. This approach will be useful in future studies of genetic diseases in mice in which a variety of human diseases has been simulated.

Intraamniotic administration of a replication-deficient adenovirus did not have detectable adverse effects. In the sheep study, all animals completed the procedures. Virus administration did not significantly alter sensitive parameters of fetal well being such as fetal arterial $\mathrm{pH}, \mathrm{PCO}_{2}, \mathrm{PO}_{2}$, hemoglobin concentration, and blood $\mathrm{O}_{2}$-saturation over $3 \mathrm{~d}$ after treatment. In the fetal mouse study, one premature delivery occurred, but it was most likely due to the surgical procedures and not due to 

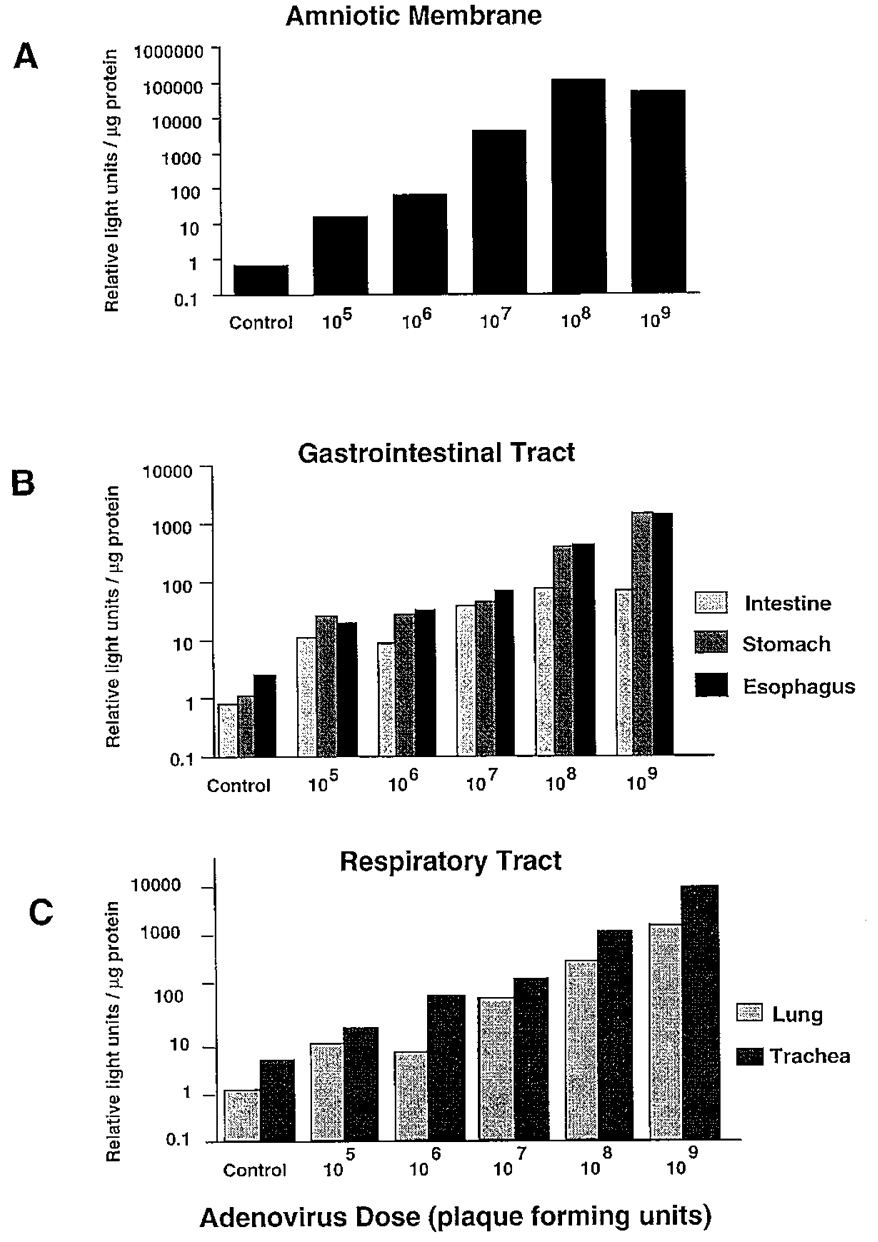

Figure 3. Adenovirus transferred specific gene expression to mouse tissues in a dose-dependent manner. A linear correlation between the dose of Av1Luc1 and luciferase gene expression as determined by luminometric quantitation in pooled fetal mouse tissue homogenates normalized for total protein content was observed. Expression levels in amniotic membranes $(A)$ were significantly higher than in all other tissues. No difference was observed between doses $10^{8}$ and $10^{9}$ pfu. Luciferase levels detected in gastrointestinal tract $(B)$ and respiratory tract $(C)$ decreased with anatomical distance from the amniotic cavity.

virus-related intrauterine fetal death, because all fetuses of all other dams survived. These preliminary data suggest the absence of short-term adverse effects of intraamniotically administered adenovirus even in relatively high doses used in the mouse study. Long-term effects, however, have not been addressed.

An inflammatory reaction related to treatment with replication-deficient adenovirus has been described by numerous investigators in various organs in a variety of species including fetal sheep $(12,24,25)$. Diffuse interstitial thickening, intraluminal neutrophils in the distal airway, and interstitial aggregates of macrophages and lymphocytes were observed in lung tissue of fetal sheep treated intratracheally with Av1LacZ4 (12). However, an inflammatory response was not demonstrated in any organ in the present study. In fetal sheep this observation can be attributed to the fact that tissues were harvested only $3 \mathrm{~d}$ after virus administration, probably before the development of an inflammatory response. The amniotic fluid volume is large relative to the injected volume and diluted the virus concentrate by as much as 1000 times. Furthermore, the low number of cells expressing the transferred gene in organs other than amniotic membrane might not be sufficient to produce a significant inflammatory response. In fetal mice, the absence of an inflammatory response may be related to immunologic immaturity of the fetal mouse that persists into early postnatal life (2).

Bacterial $\beta$-galactosidase and luciferase were expressed at various levels in the organs analyzed. Because adenovirus was instilled into the amniotic cavity, it is not surprising that expression levels in amniotic membrane were significantly higher than in any other organ. The variable density of cells expressing bacterial $\beta$-galactosidase detected with histologic methods in sheep amniotic membranes may be related to naturally occurring tissue folds creating areas less accessible to the virus. Furthermore, fetal movements made the precise location of the amniotic cavity catheter at the time of virus injection variable. Even distribution of intraamniotically administered substances normally occurs within a short period of time unless a substance is administered directly onto the hairy surface of the fetus, where the viscosity of amniotic fluid is high and mixing is apparently low (Iwamoto HS, unpublished observation). In sheep the efficiency of transfer of the $l a c Z$ gene to gastrointestinal and respiratory tract appeared to be low. Higher densities of cells expressing bacterial $\beta$-galactosidase in fetal mice are due to the relatively higher dose regarding the distribution volume. More sensitive histologic or biochemical methods, however, might be able to detect expression of the transferred gene in ovine cells where it would not be detected by enzyme-histochemistry. The lack of adverse effects in the present study suggests that higher doses resulting in higher levels of expression of the transferred gene in respiratory and gastrointestinal tract might be feasible. Reliable data about the required level of expression of a transferred gene in a certain organ for a given genetic defect to significantly alter the natural course of a genetic disease are not yet available.

The linear dose response in the luciferase studies indicates that adenoviral constructs are reliable vectors for somatic gene transfer. They also support the intraamniotic route of administration as a method to deliver genes to fetal tissues. The efficiency of this approach, however, appears to be low for tissues other than amniotic membrane. The Rous sarcoma virus promoter used in the adenoviral constructs of the present study directed expression of the transferred gene in numerous cell types. In the future, specific promoters could be used to restrict expression of the transferred gene to specific tissues or cells of interest.

The ability to transfer genes to fetal tissues in utero could be useful in the correction of a variety of genetic diseases. In addition to a desired permanent correction of a defect, temporary expression of transferred genes could be sufficient to gain time for other treatments to become feasible (e.g. lung transplant in surfactant protein B deficiency). Genes that are developmentally not expressed yet in immature individuals (such as surfactant proteins) or genes the product of which confers protection from adverse effects of a therapeutic agent (e.g. superoxide dismutase in oxygen injury) could also be trans- 
ferred. Gene products efficiently expressed in and secreted from amniotic membranes could be absorbed by the fetus and hold a potential for transferring a therapeutic agent to the fetus.

Acknowledgments. The authors thank Christine Kane and Carol McConnell for their excellent technical assistance and Nanette Mittereder for her contribution in the production of recombinant adenovirus.

\section{REFERENCES}

1. Rosenfeld MA, Siegfried W, Yoshimura K, Yoneyama K, Fukayama M, Stier LE, Pääkkö P, Gilardi P, Stratford-Perricaudet LD, Perricaudet M, Jallat S, Pavirani A, Lecocq JP, Crystal RG 1991 Adenovirus-mediated transfer of a recombinant $\alpha-1$ antitypsin gene to the lung epithelium in vivo. Science 252:1059-1065

2. Quantin B, Perricaudet LD, Tajbakhsh S, Mandel J-L 1992 Adenovirus as an expression vector in muscle cells in vivo. Proc Natl Acad Sci USA 89:2581-2584

3. Rosenfeld MA, Kunihiko Y, Trapnell BC, Yoneyama K, Rosenthal ER, Dalemans W, Fukayama M, Bargon J, Stier LE, Stratford-Perricaudet L, Perricaudet M, Guggino WB, Pavirani A, Lecocq J-P, Crystal RG 1992 In vivo transfer of the human cystic fibrosis transmembrane conductance regulator gene to the airway epithelium. Cell 68:143-155

4. Engelhardt JF, Simon RH, Yang Y, Zepeda M, Weber-Pendleton S, Doranz B, Grossman M, Wilson JM 1993 Adenovirus-mediated transfer of the CFTR gene to the lung of nonhuman primates: biological efficacy study. Hum Gene Ther 4:759-796

5. Yei S, Weaver TE, Whitsett JA, Trapnell BC 1993 Direct in vivo transfer and expression of the normal human surfactant protein B CDNA in epithelium of the respiratory tract using an adenoviral vector. Pediatr Pulmonol Suppl 9:246A

6. Smith TA, Mehaffay MG, Kayda DB, Saunders JM, Yei S, Trapnell BC, McClelland A, Kaleko, M 1993 Adenovirus mediated expression of therapeutic plasma levels of human factor IX in mice. Nat Genet 5:397-402

7. Mastrangeli A, Danel C, Rosenfeld MA, Stratford-Perricaudet L, Perricaudet M, Pavirani A, Lecocq J-P, Crystal RG 1993 Diversity of airway epithelial cell targets for in vivo recombinant adenovirus-mediated gene transfer. J Clin Invest 91:225-234

8. Nogee LM, DeMello DE, Dehner LP, Colten HR 1993 Deficiency of pulmonary surfactant protein B in congenital alveolar proteinosis. N Engl J Med 328:406-410

9. Hamvas AF, Cole FS, DeMello D, M M, Whitsett J, Nogee L 1993 Inherited surfactant protein B (SP-B) deficiency: effects of surfactant replacement. Pediatr Res $33: 328 \mathrm{~A}$
10. DeMello DE, Nogee L, Heyman S, Krous H, Phelps D, Colten HR 1993 Inherited surfactant protein B (SP-B) deficiency in congenital alveolar proteinosis (CAP). Pediatr Res 33:127A

11. Nogee L, Hull W, Whitsett J, Hamvas A, Cole FS 1993 Inherited surfactant protein B (SP-B) deficiency: prenatal diagnosis. Pediatr Res 33:227A

12. Vincent MC, Trapnell BC, Baughman RP, Wert SE, Whitsett JA, Iwamoto HS 1995 Adenovirus-mediated gene transfer to the respiratory tract of fetal sheep in utero. Hum Gene Ther 6:1019-1028

13. McCray PB, Armstrong K, Zabner Miller DB, Koretzky GA, Couture L, Robillard JE, Smith AE, Welsh MJ 1995 Adenoviral-mediated gene transfer to fetal pulmonary epithelia in vitro and in vivo. $\mathrm{J}$ Clin Invest 95:2620-2632

14. Duenholter JH, Pritchard JA 1974 Human fetal respiration. II. Fate of intra-amniotic Hypaque and $51 \mathrm{Cr}$-labeled red cells. Obstet Gynecol 43:878-883

15. Galan HL, Kuehl TJ 1992 Effect of intra-amniotic administration of exosurf in preterm rabbit fetuses. Obstet Gynecol 80:604-608

16. Galan HL, Cipriani C, Coalson JJ, Bean JD, Collier G, Kuehl TJ 1993 Surfactant replacement therapy in utero for prevention of hyaline membrane disease in the preterm born baboon. Am J Obstet Gynecol 169:817-824

17. Sanes JR, Rubenstein JL, Nicolas JF 1986 Use of recombinant retrovirus to study post-implantation cell lineage in mouse embryos. EMBO J 5:3133:3142

18. Brasier AR, Tate JE, Habener JF 1989 Optimized use of the firefly luciferase assay as a reporter gene in mammalian cell lines. Biotechniques 7:1116-1122

19. Yei S, Mittereder N, Wert S, Whitsett JA, Wilmott RW, Trapnell BC 1994 In vivo evaluation of the safety of adenovirus-mediated transfer of the human cystic fibrosis transmembrane conductance regulator CDNA to the lung. Hum Gene Ther 5:731-744

20. Yei S, Mittereder N, Tang K, O'Sullivan C, Trapnell BC 1994 Adenovirus-mediated gene transfer for cystic fibrosis: quantitative evaluation of repeated in vivo vector administration to the lung. Gene Ther 1:192-200

21. Lowry OH, Rosebrough NJ, Farr AL, Randall RJ 1951 Protein measurement with the Folin phenol reagent. J Biol Chem 193:265-275

22. Brody LS, Metzger M, Danel C, Rosenfeld MA, Crystal RG 1994 Acute responses of non-human primates to airway delivery of an adenovirus vector containing the human cystic fibrosis transmembrane conductance regulator cDNA. Hum Gene Ther 5:821836

23. Lemarchand P, Jones M, Yamada I, Crystal RG 1993 In vivo gene transfer and expression in normal uninjured blood vessels using replication-deficient recombinant adenovirus vectors. Circ Res 72:1132-1138

24. Yang Y, Nunes FA, Berencsi K, Furth EE, Gönczöl E, Wilson JM 1994 Cellular immunity to viral antigens limits E1-deleted adenoviruses for gene therapy. Proc Nat Acad Sci USA 91:4407-4411

25. Simon RS, Engelhardt JF, Yang Y, Zepeda M, Weber-Pendleton S, Grossman M, Wilson JM 1993 Adenovirus-mediated transfer of the CFTR gene to lung of nonhuman primates: toxicity study. Hum Gene Ther 4:771-780 